\title{
Killer Cell Immunoglobulin-Like Receptor 2DS4
}

National Cancer Institute

\section{Source}

National Cancer Institute. Killer Cell Immunoglobulin-Like Receptor 2DS4. NCI Thesaurus. Code $C 118918$.

Killer cell immunog lobulin-like receptor 2DS4 (304 aa, 34 kDa) is encoded by the human KIR2DS4 gene. This protein plays a role in the modulation of natural killer cell activity. 